by Erika Kido ${ }^{l}$, Thomas J. Suttner ${ }^{l}$, Johnny A. Waters ${ }^{2}$, Ariunchimeg Yarinpil ${ }^{3}$, Sersmaa Gonchigdorj', James W. Atwood ${ }^{5}$ and Gary D. Webster ${ }^{6}$

\title{
Devonian deposits of the Baruunhuurai Terrane, western Mongolia (IGCP 596 Field Workshop)
}

\author{
1 University of Graz - Institute for Earth Sciences (Geology and Paleontology), Heinrichstrasse 26, A-8010 Graz, Austria. \\ E-mail: erika.kido@uni-graz.at; thomas.suttner@uni-graz.at \\ 2 Department of Geology, Appalachian State University, Boone, NC 28608, USA. E-mail: watersja@appstate.edu \\ 3 Palaeontological Centre, Mongolian Academy of Sciences, Ulaanbaatar-46/52, Mongolia. E-mail: ariuna_ya@magicnet.mn \\ 4 Mongolian University of Science and Technology, Ulaanbaatar, 46/520, Mongolia.E-mail: sers_gon@yahoo.com \\ 5 Earth and Planetary Sciences, University of Tennessee, 306 Earth and Planetary Sciences Building, Knoxville, TN 37996, USA. \\ E-mail: jatwood2@utk.edu \\ 6 School of the Environment, Washington State University, PO Box 642812, Pullman, WA 99164-28112, USA.E-mail: webster@wsu.edu
}

IGCP 596 (2011-2015) has a primary focus on climate change and biodiversity patterns in the Mid-Paleozoic (Early Devonian to Late Carboniferous). As a part of this project, we conducted a field workshop in western Mongolia in the summer of 2012. The goal was to locate fossiliferous sections that expose the stage boundaries from the Eifelian/Givetian boundary (Middle Devonian) to the Devonian / Carboniferous boundary to expand our knowledge of the key Devonian biotic and geochemical events such as the Frasnian / Famennian extinction event and the Kacák, Kellwasser and Hangenberg oceanographic events. During the field workshop, we examined sections in the Nariinhar Formation, Baruunhuurai Formation and Samnuuruul Formation from the Baruunhuurai Terrane.

\section{Introduction and Background}

The Frasnian / Famennian event is one of the Big Five extinction events first published by Raup and Sepkoski (1982). Subsequent work has shown that a number of biodiversity crises occurred in the Middle and Late Devonian including the Givetian / Frasnian event, the Frasnian / Famennian event and the Devonian / Carboniferous event. Taxonomic severity ranking of the 11 largest Phanerozoic biodiversity crises by Sepkoski (1996) placed the F/F event at number six with a taxonomic loss of 35\%, the Givetian / Frasnian event, at number seven with a taxonomic loss of $30 \%$ and the $\mathrm{D} / \mathrm{C}$ event at number eight with a loss of $28 \%$. A similar ranking proposed by Bambach et al. (2004) placed the F/F event at number six, the G/F event at number seven and the D/C event at number nine. McGhee et al. (2013) rank the $\mathrm{D} / \mathrm{C}$ event as the fourth and the $\mathrm{F} / \mathrm{F}$ event as the fifth most severe biodiversity crisis since the beginning of the Ordovician. The G/F event was ranked number seven.

McGhee et al. (2012) developed a new ecological severity ranking in an attempt to expand the discussion of biodiversity crises beyond measures of taxonomic loss in the extinction events. Using this analysis, they ranked the F/F event as the fourth most ecologically severe crisis in the Phanerozoic of the six events ranked. All the analyses conclude that the Middle and Late Devonian was a time of biotic crisis that spanned many millions of years. Middle Devonian events may not have reached the ecological severity of the F/F event, but the $\mathrm{G} / \mathrm{F}$ event was a significant extinction event for echinoderms and bryozoans and for the replacement of endemic marine faunas by more cosmopolitan ones (McGhee et al. 2013). The Middle Devonian was the time of rapidly increasing diversification of tree-like vegetation on land, the development of root-systems and the formation of soil (Algeo and Scheckler, 1998; Stein et al. 2007), which dramatically changed atmospheric $\mathrm{CO}_{2}$ and climates. Although many DevonianCarboniferous sections contain evidence of these extinction and anoxic events, we have been conducting fieldwork in northwestern China and now Mongolia not only to expand the global scale of such studies, but also to examine stratigraphic sections deposited on volcanic island arc systems (Jahn et al. 2000; Chen and Arakawa, 2005; Cocks and Torsvik, 2007; Windley et al. 2007; Wainwright et al. 2011; Xiao et al. 2010), which may have served as refugia in the aftermath of major biotic extinction events.

\section{The Middle and Late Devonian in the Junggar Basin}

The Hongguleleng Formation exposed in the western Junggar Basin (NW Xinjiang, China), is one of the few localities in the world with richly fossiliferous Famennian sedimentary rocks deposited in a shallow marine setting. Current estimates of biodiversity in the Hongguleleng exceed 100 genera. Major paleontologic, sedimentologic and biostratigraphic studies include the following: Zhao (1986), Liao and Cai (1987), Hou et al. (1988, 1993), Lu and Wicander (1988), Zhao and Wang (1990), Xiao et al. (1992), Gong and Liu (1993), Xia (1997), Lane et al. (1997), Xu (1999), Soto and Lin (2000), Waters et al. (2003, 2008), Chen et al. (2009), Ma et al. (2009, 2011), Webster and Waters (2009), Waters and Webster (2009). In addition Lane et al. (1997), Waters et al. (2003), and Waters and Webster (2009) were able to document a rapid and evolutionarily advanced rebound by echinoderms from the Frasnian / Famennian 
mass extinction from collections made in the Hongguleleng. They also hypothesized that the Hongguleleng was a Famennian refugium given its deposition in a Paleo-Tethyan island arc complex, a view shared by McGhee et al. (2013).

Suttner et al. (accepted) increased the significance of the Hongguleleng Formation by demonstrating that the F/F boundary is contained within the lower 3 meters of the formation. Our recent work on the Hongguleleng has concentrated on a detailed geochemical analysis of the uppermost Frasnian and F/F boundary interval in the Hongguleleng. Initial results indicate geochemical excursions typically associated with the Upper Kellwasser Event. The Devonian Working Group continues to study the sedimentology, geochemistry, and biostratigraphy of the Hongguleleng type section and is also addressing the hypothesis that the formation contains other Famennian anoxic events including the Hangenberg Event and the D/C boundary extinction event. In summary, the Hongguleleng Formation is rare in that it contains the Upper Kellwasser Event, the F/F boundary extinction event, and shallow marine faunas that document the rapid rebound from the extinction with the tantalizing prospect of containing other Famennian anoxic events and the D/C extinction. Given the significance of these biotic crises, the Hongguleleng represents a rare, but highly important window, into this critical interval of earth history.

Marine transgression and limestone deposition observed in the Hongguleleng Formation are rare in the western Junggar Basin during the Middle Devonian. Deposits are characterized mainly by a sequence of tuffs, tuffaceous sandstones and conglomerates dominated by plant fossils (Xiao et al. 1992, Cai 2000, Ma et al. 2009). Marine organisms, such as corals and brachiopods, occur only in thin limestone intervals of the Hefeng Formation deposited during the early Eifelian (Xu, 1991; Ma et al. 2009). Several hundred kilometers farther southeast, an abundant marine fauna is reported by Zhu et al. (2008) within the lower and middle part of the Ulusubasite Formation of the Zhifang section (eastern Junggar Basin, China). Marine and terrestrial fossils indicate an Eifelian age for this unit (Hou et al. 2000). Because the Eifelian / Givetian boundary is based on conodonts from the Tsakhir section near Shine Jinst in the Gobi Altai Region (Sersmaa 2001, Aristov \& Nyamsuren 1996, Sullivan 2010), studying Middle to Late Devonian sections from the eastern Junggar Basin but located in western Mongolia is critical. In summary, the paleontological and geochemical studies from the Junggar Basin in Xinjiang form a regional basis to explore other regions of Asia for similar sections.

\section{Results of the Field Workshop}

Ariunchimeg (2000) reported Famennian faunas from isolated outcrops in the Baruunhuurai Terrane of western Mongolia. The Baruunhuurai Terrane contains a series of Devonian island arc complexes and is equivalent to the tectonic terrane exposed in northwestern Xinjiang. In 2012, members of the Western Mongolia Devonian Working Group conducted a field workshop in the Baruunhuurai Terrane (Fig. 1) and investigated several localities. Five are introduced here. These sections are geographically located between

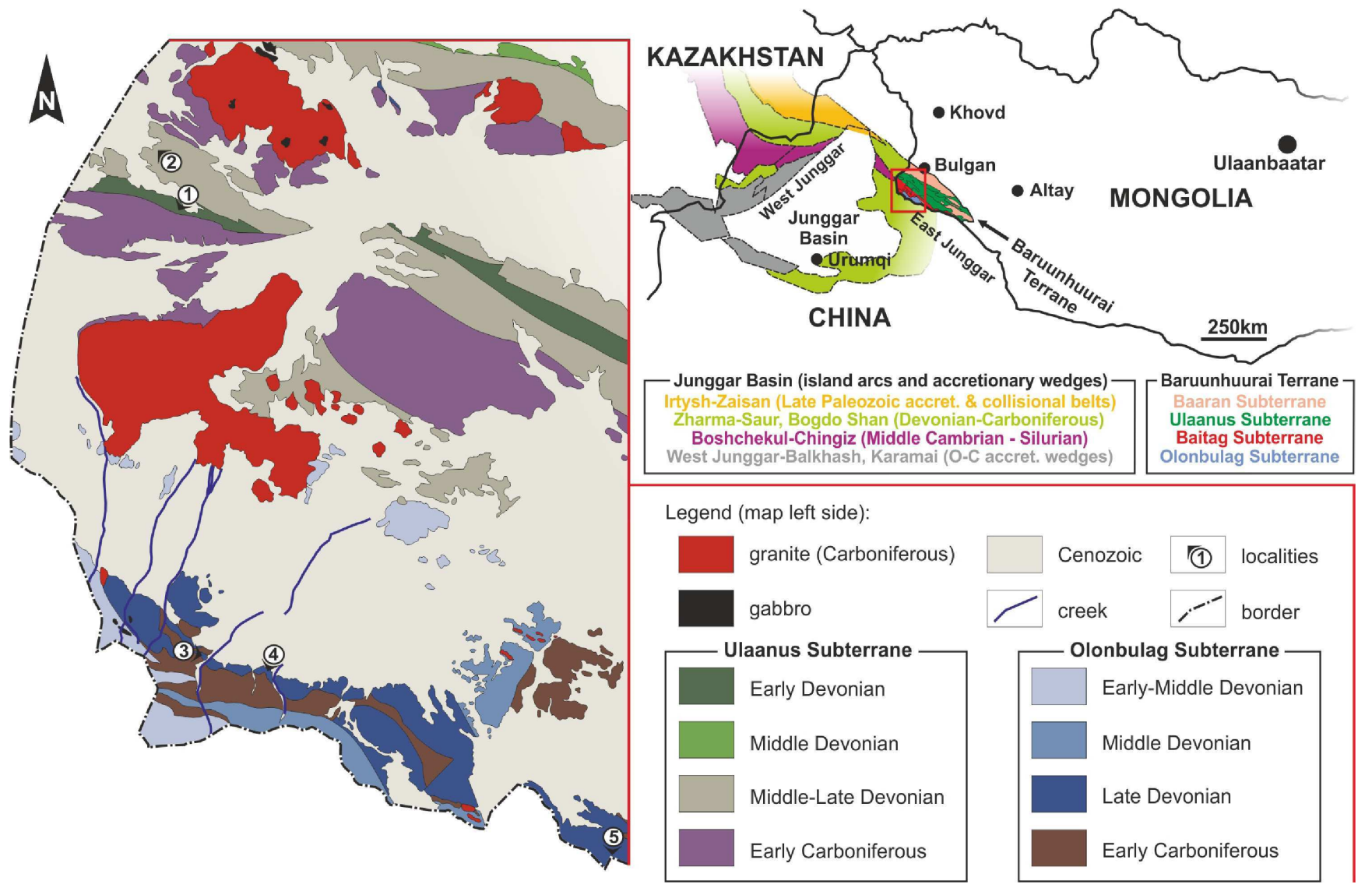

Figure 1. Locality map showing the subdivision of the Baruunhuurai Terrane, western Mongolia and its relation to the Junggar Basin, northwestern China (based on Ma et al. 2009 and Xiao et al. 2010). A geological map of the observed area is illustrated on the left side (simplified after Badarch et al. 1998). 
sections exposed in the Junggar Basin in northwestern Xinjiang (Ma et al. 2009) and exposures in the Santanghu Basin in eastern Xinjiang (Chen and Archbold, 2002).

\section{The Baruunhuurai Terrane}

The Baruunhuurai Terrane is subdivided into four subterranes (Baaran, Olonbulag, Ulaanus and Baitag Subterrane) (Badarch et al. 1998; Dergunov, 2001). The units observed during the FieldWorkshop (Fig. 1) belong to the Ulaanus Subterrane (Nariinhar Formation: Early Devonian; Baruunhuurai Formation: Middle to Late Devonian), and the Olonbulag Subterrane (Samnuuruul Formation: Late Devonian). Stratigraphic relationships of these formations are shown in Fig. 2. Lithology, fossil content and depositional environment for each unit are discussed below.

\section{The Nariinhar Formation}

The outcrop of the Nariinhar Formation (Loc. 1; Figs. 1-5; GPS coordinates $45^{\circ} 45^{\prime} 16^{\prime \prime} ; 90^{\circ} 53^{\prime} 30^{\prime \prime}$ ) is located in an intensely deformed zone and continues laterally for approximately $2 \mathrm{~km}$ until major fault

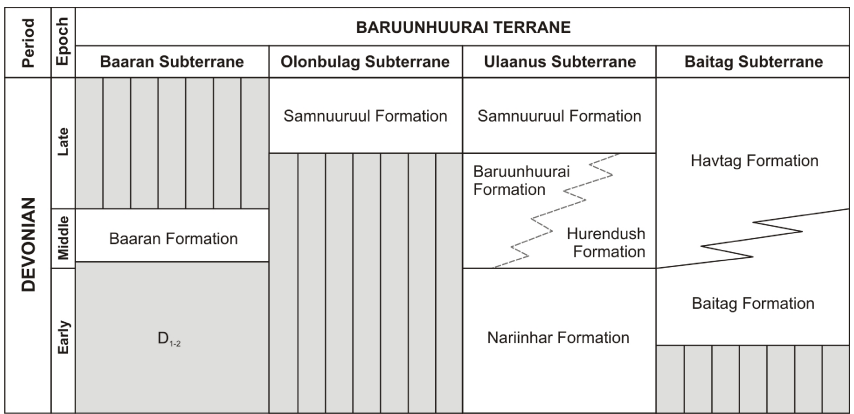

Figure 2. Lithostratigraphical correlation of Devonian formations of the Baruunhuurai Terrane.

zones displace the unit in the East. The formation in this area is traceable for $13 \mathrm{~km}$ laterally. The Nariinhar Formation is $50-60 \mathrm{~m}$ thick and consists of decametric scale bedded bright gray marble beds (dipping: 025/75) bounded by green to brownish tuffaceous deposits at the base and top (Fig. 3). Fossil-rich levels yield abundant articulated crinoid stems reaching a length of 15 to $20 \mathrm{~cm}$ with a diameter of about $1.5 \mathrm{~cm}$ (Figs. 4 and 5). As far as preserved, the
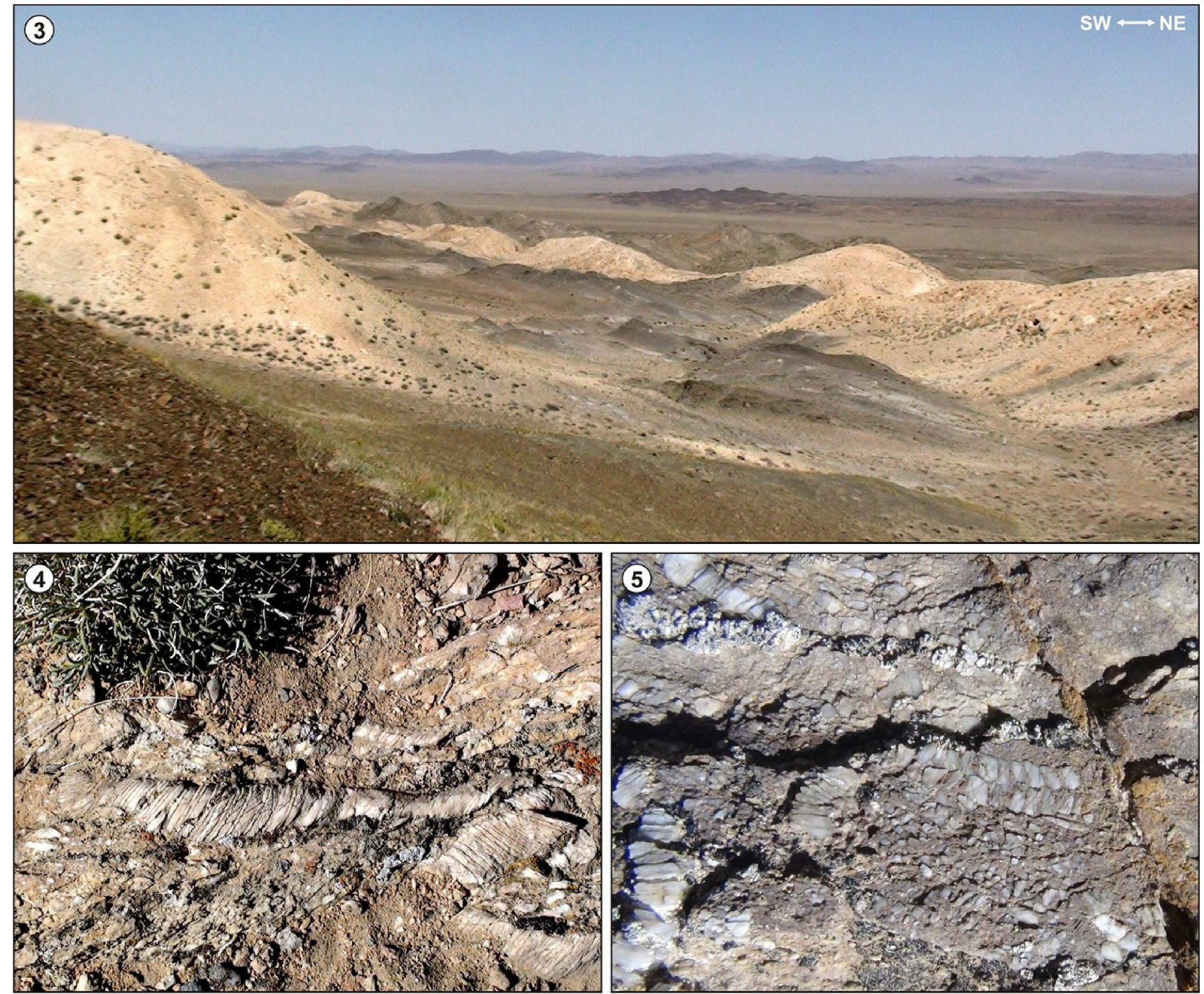

Figures 3-5. 3: Panoramic view of the folded outcrop in the Nariinhar Formation (indicated as Loc. 1 in Fig. 1). 4, 5: articulated crinoid ossicles of different stratigraphic levels within the sedimentary sequence. 
Nariinhar Formation reflects deposition on an ephemeral carbonate platform in a volcanically active terrane. Based on the crinoid species Pentagonocyclicus glaber and Pandocrinus aff. plicatus the age of Nariinhar Formation was determined as Early Devonian in the map (scale 1:200 000) reported by U. Davaa et al. in 1994. They correlated the Nariinhar Formation with the Asushan Formation of Xinjiang. In 2008-2009 N. Batbayar et al. produced a map (1:50 000) of this area from the border to $91^{\circ} 45^{\prime} 00^{\prime \prime}$ and between $45^{\circ} 30^{\prime} 00^{\prime \prime}$ to $45^{\circ} 50^{\prime}$ 00", and suggested Middle Devonian age of the formation. However, an Early Devonian age is proposed by latest investigations of regional mapping geologist.

\section{The Baruunhuurai Formation}

The Baruunhuurai Formation outcrops on several hills (Figs. 1-2 and 6) at GPS coordinates 45 48'36"; 90 53'10" (ridge 1 in Fig. 6). The strata are steeply dipping to vertical southwest to northeast in outcrop. At least two levels of igneous rocks (intrusions ?) are recognized parallel to bedding (Fig. 9-A). We measured 4 sections (A-A' to D-D'; Fig. 9-B) to document the lateral and vertical continuity of the sequence in the outcrop and to determine the relationships of fossil-rich levels observed in each of the small hills. The dominant deposits of the sequence are tuffaceous siliciclastics, which show a successive change in color from green to yellow across the section. We divided the formation into three units according to the dominant facies.

The lower unit is composed primarily of shale, siltstone, and sandstone (spanning the interval of section $\mathrm{A}-\mathrm{A}^{\prime}$ ). The facies and thickness of the beds vary laterally between the two levels of igneous rocks and include calcareous shale and a few limestone layers restricted to the vicinity of section B-B'. The middle unit (starting above bed 58, the second level of igneous rocks, and continuing to the top of bed 62 in section $\mathrm{C}_{1}-\mathrm{C}_{1}{ }^{\prime}$ ) is characterized by shale deposition intercalated by thin beds of limestone. The upper part of the section $\mathrm{C}_{1}-\mathrm{C}_{1}{ }_{1}$ is more calcareous corresponding to the limestone beds in section D-D', where a change of facies and an increase in limestone thickness is observed laterally. The upper unit (= section $\left.\mathrm{C}_{2}-\mathrm{C}_{2}{ }^{\prime}\right)$ consists of shale with intercalations of thin sandy unfossiliferous limestone lenses, silty shale to siltstone, and are overlain by a thick interval of yellowish to brown shale.

Fossils are found in slightly elevated hills (Fig. 6) and are represented by rugose and tabulate corals, trilobites, bivalves, brachiopods, bryozoans, crinoids and fish dermal plates (Figs. 7, 8). Fossils occur in the lower and middle units of the section and are preserved as molds and casts (Figs. 7 and 8). A large collection of crinoid stems was obtained from the section D-D'. In the section $\mathrm{C}_{1}$ $\mathrm{C}_{1}$, , rugose corals were collected from four levels (BAK3/48, 3/62e, rubble of $3 / 62 \mathrm{j}$ and $3 / 62 \mathrm{o}$ ), whereas tabulate corals are found only in two beds (BAK3/62e and 3/62g). The rugose corals are characterized by trochoid to conical solitary corallia one to seven $\mathrm{cm}$ in length. Specimens with the largest corallia were found in the scree of the shale-interval of bed BAK3/62j. Bryozoan colonies, corals and crinoid ossicles occur in all four sections, whereas the bivalves and fish remains were found only at the hill 2 (= section B-B') and hill 8 , respectively. Based on the fossils obtained and the preliminary lithofacies analysis, the Baruunhuurai Formation in this area was
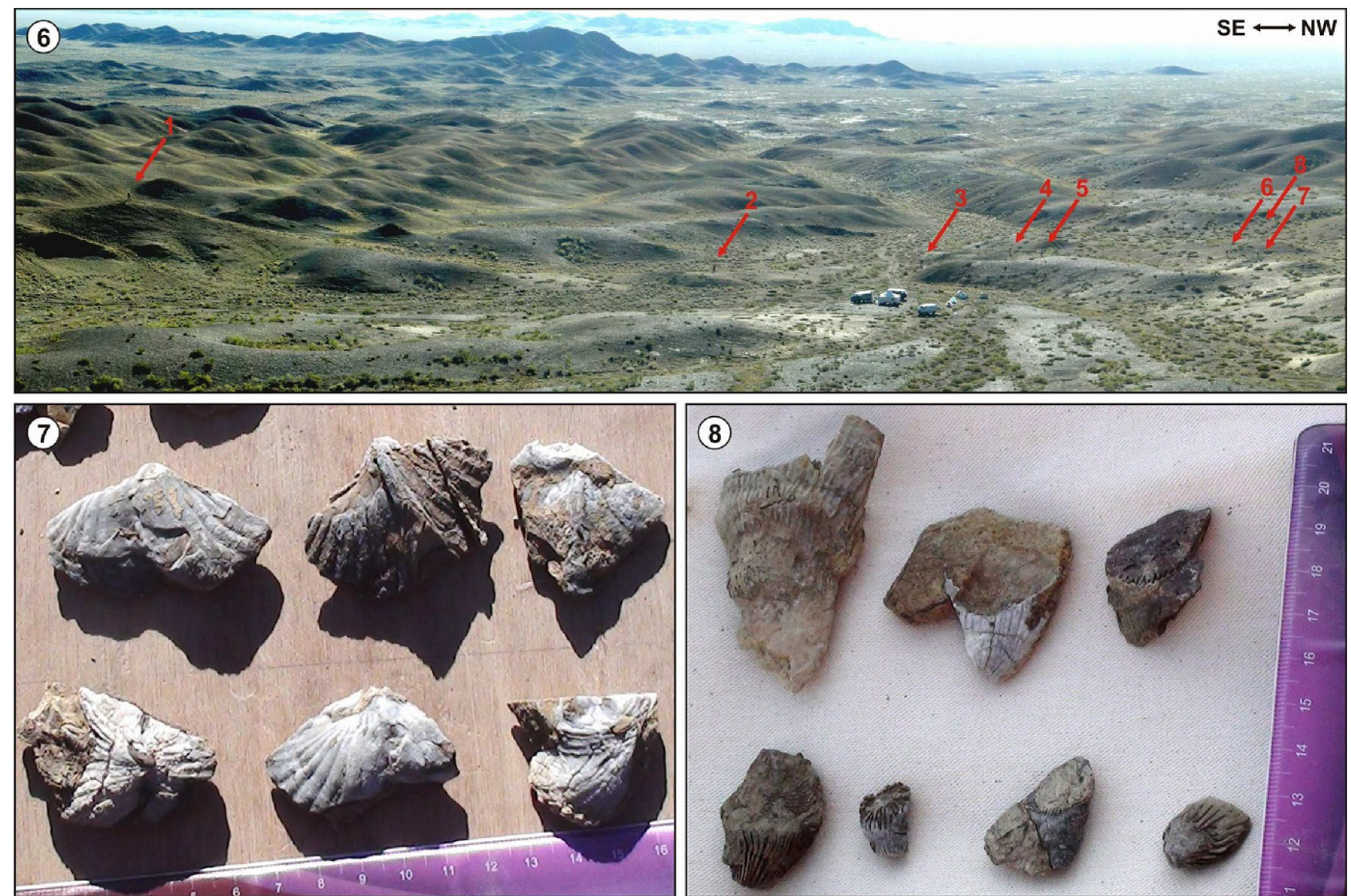

Figures 6-8. 6: Panoramic view of the outcrop in the Baruunhuurai Formation (indicated as Loc. 2 in Fig. 1). The numbers (1-8) show small hills where the fossils were collected from. 7, 8: Brachiopods and rugose corals from the Baruunhuurai Formation, respectively. 


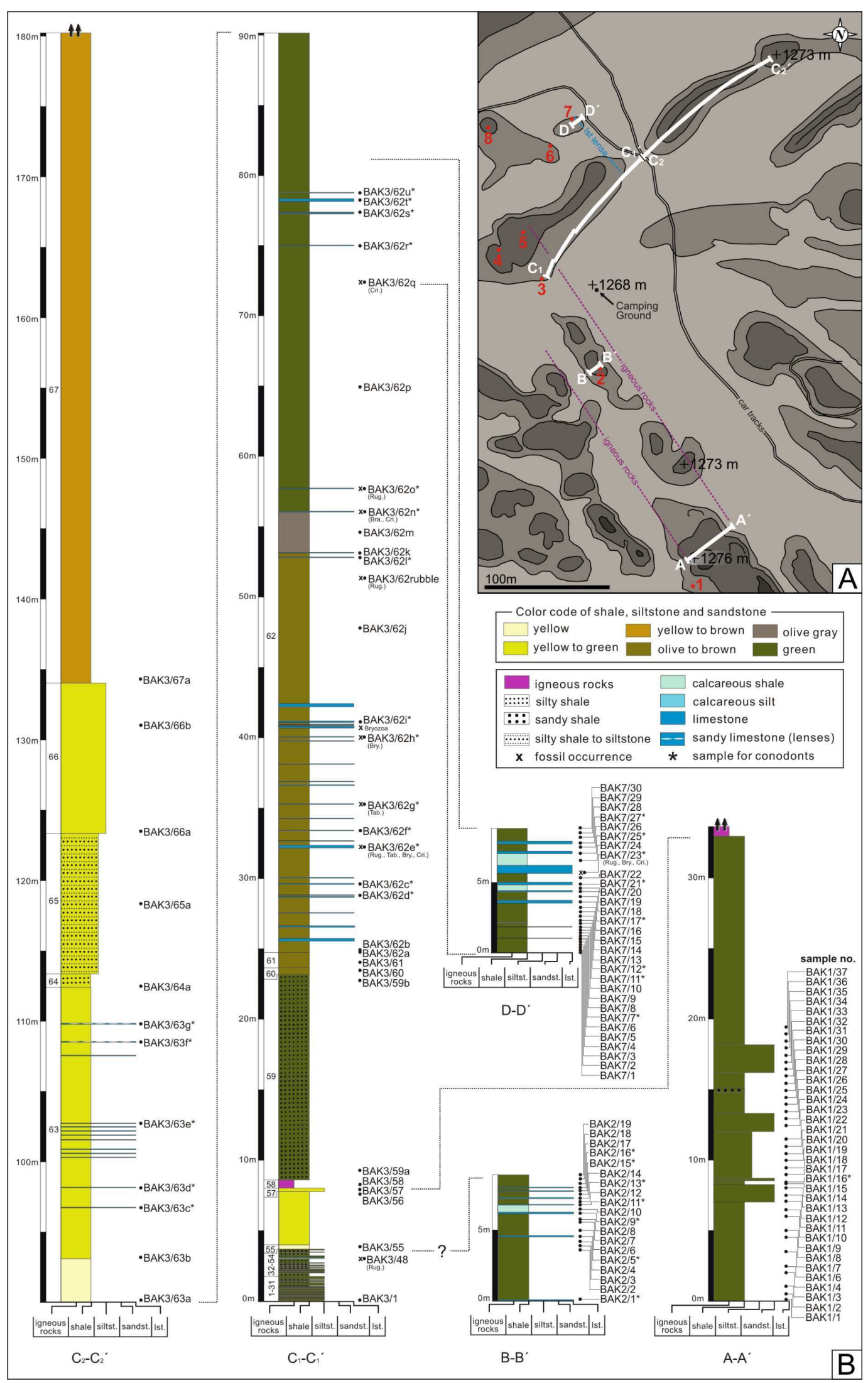

Figure 9. A: A rough topographic map of Loc. 2 showing the numbers of hills (see Fig. 6), allocation of the columnar sections measured (A$A^{\prime}$ to D-D'). Purple lines indicate laterally continuing exposures of two levels of the igneous rocks, and one blue line highlights a limestone lense laterally traceable between the sections $C_{1}-C_{1}$ ' and D-D'. B: Measured columnar sections (A-A'to D-D') across fossil bearing intervals of the Baruunhuurai Formation. Sections provide details on the lithological content and show the stratigraphic position of collected samples for geochemistry and fossils. 
deposited in a shallow marine nearshore setting with regionally dispersed limestone lenses produced by locally restricted fossil communities and intermittent volcanically derived sediment. In Dergunov (2001), brachiopods (Stropheodonta cf. interstrialis, S. asella, Cariniferella tioga, Productella jubaculeata, Atrypa sp., Cyrtospirifer shelonicus), conodonts (Polygnathus costatus patulus, P. communis communis, Pelekysgnathus sp., Icriodus ex gr. corniger, Bispathodus stabilis) and tabulate corals (Cladopora kokscharskaje, Thamnopora nicholsoni, T. cervicornis) have been reported from the
Baruunhuurai Formation. Based on these fossils the formation was referred to range from the Eifelian to the Frasnian (Dergunov, 2001). Ulitina (2001) reported rugose corals from the same formation cropping out in the vicinity of the Zagiin-Hara-Uul Mountains, west of Ih-Shovgor Mountain, and on the southern slope of the IndrengiinNuruu Range. They are Nicholsoniella hurenensis, N. golovtshenkoae, Aulacophyllum exiguum and Temnophyllum ruzhentsevi. Based on the rugose corals and on brachiopods (Cariniferella ulitinae, Streptorhynchus sp., Protoleptostrophia sp., Desquamatia (Seratrypa)
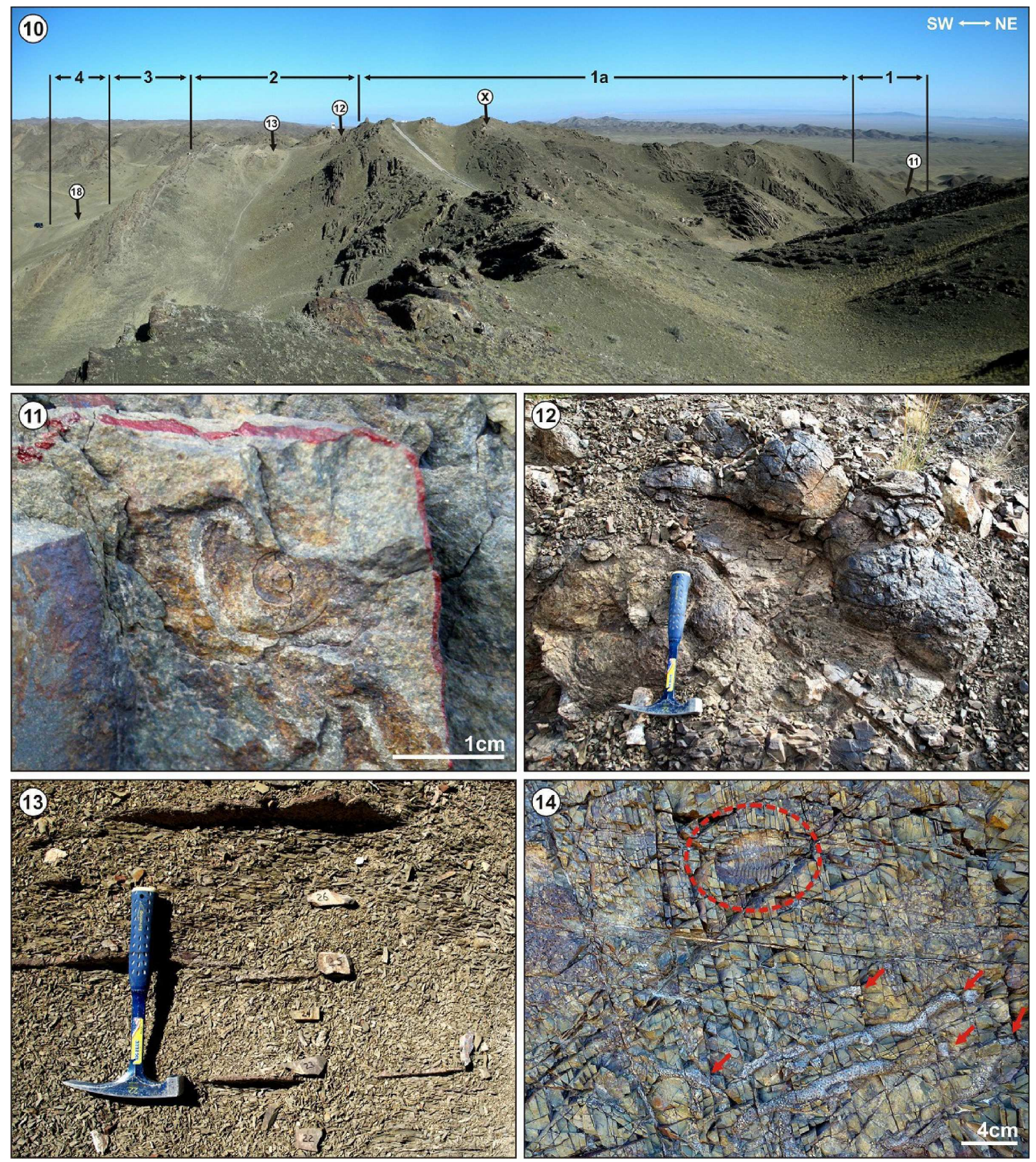

Figures 10-14. 10: Panoramic view of the outcrop in the Samnuuruul Formation (indicated as Loc. 3 in Fig. 1). In order to achieve a bedby-bed profile in short time, we formed five working groups which resulted in the subdivision of five somehow lithological constrained intervals (units 1, 1a, 2, 3 and 4). Minivan for scale on far left. 11: Small mollusc shell collected from unit 1 in Figure 10. 12: Pillow structures in siltstones from unit 2. 13: Fossiliferous, fissile, green shale and discontinuous limestone from unit 2. 14: phacopid trilobite and ramose branching tabulate coral on vertical siltstone beds from unit 3. 
pectinata, D. (Independatrypa) sp., Adolfia loriger, Cyrtiopsis sp. and Cyrtospirifer sp.) she suggested a Frasnian age for the deposits of the Baruunhuurai Formation. Erlanger (1994) also described Frasnian brachiopods (Bulgania mongolica) from the Zagiin-HaraUul Mountains. Further taxonomic and stratigraphic works of the faunas collected from the studied area of the Baruunhuurai Formation are ongoing.

\section{The Samnuuruul Formation}

We measured a section in the Samnuuruul Formation located at 45 ${ }^{\circ} 17^{\prime} 06$ "; 90 9 57’31" (Loc. 3; Figs. 1, 2 and 10-20). This was the section from which Ariunchimeg (2000) first reported Famennian bryozoans from Mongolia. The bryozoans were correlative with the Simorinskii horizon in Kazakhstan, the Upper Famennian in the Rudny Altai, the Middle crepida Biozone in northwestern China and the Etroeungtian of Japan. Ariunchimeg (2000) also reported the presence of Quasiendothyra dentata, an index fossil of the Etroeungtian of Europe and the brachiopod Cyrtospirifer ivanovae, a fossil characteristic of the Kuznetsk basin. These fossils support the late Famennian age of the Samnuuruul Formation. In addition, many of the bryozoans have close affinity with bryozoans reported by Xia (1997) from the Hongguleleng Formation in Xinjiang. Ulitina reported the rugose coral Amplexus echinatus from the left bank of Hushoot Shiveetiin gol in the Samnuuruul Formation (Bol'shakova et al. 2003).
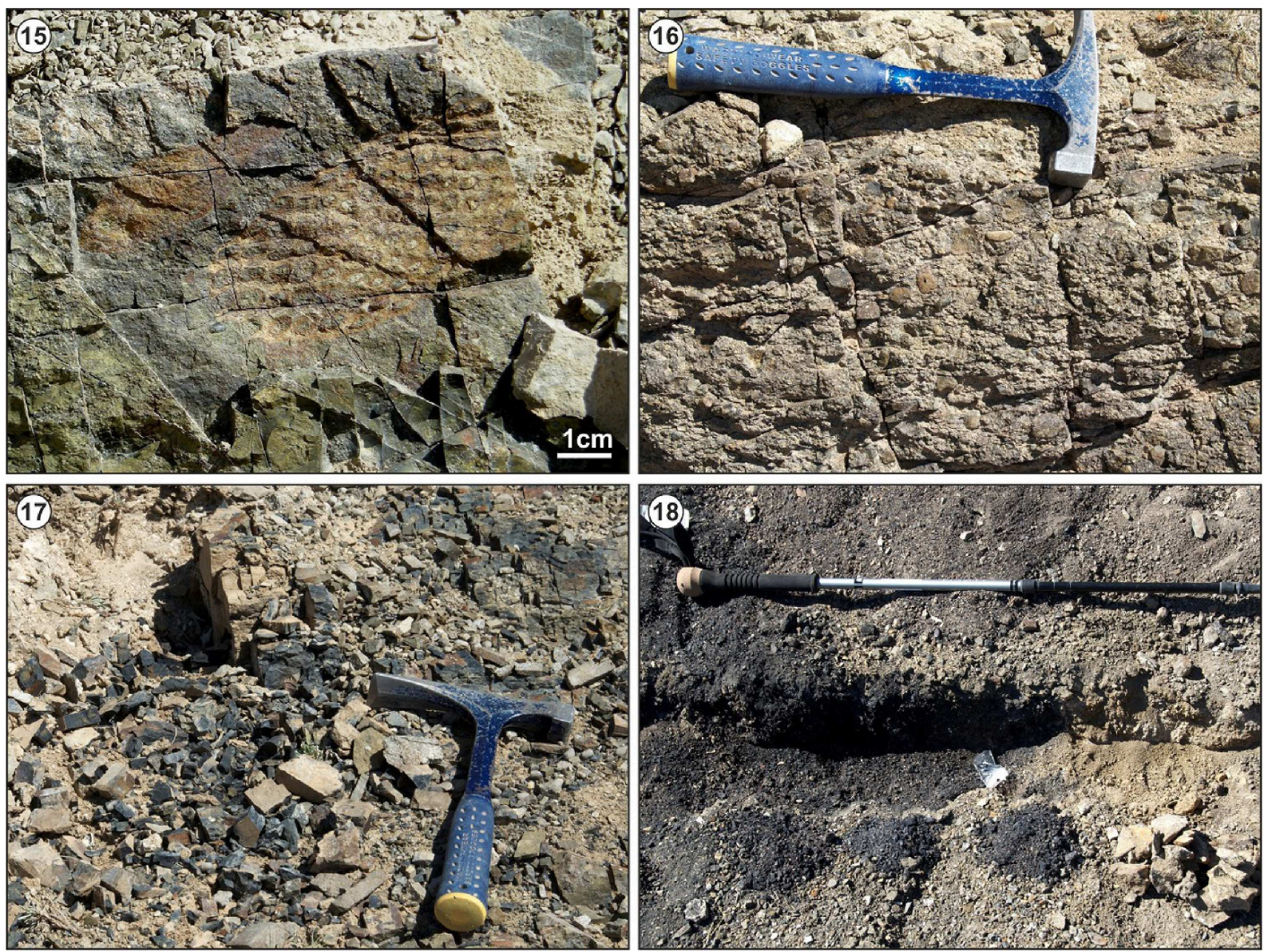

Figures 15-18. Photos from unit 4 of the Samnuuruul Formation in Figure 10. 15: Large chunk of lycopsid stem. 16: Coarsening upward sandstone sequence. 17: Black shale hypothesized to represent the Hangenberg Event. 18: Soil horizon and carbonaceous shale at the D/Cboundary.
The Samnuuruul Formation outcrops in an area that has been subjected to folding, faulting, and extensive fracturing from joint sets. This tectonic overprint has hampered our ability to completely characterize the stratigraphy and biota of the formation. This is especially true in the lower $330 \mathrm{~m}$ of units 1 and 1a (Fig. 10). All units were measured bed-by-bed, but due to the problematic stratigraphic relations in the field, only lithological columns of the units 2, 3 and 4 are figured here (Figs. 19 and 20). A small, but significant collection of brachiopods, gastropods and cephalopods was collected from a siltstone cliff about $30 \mathrm{~m}$ above the base of the section (Figs. 10 and 11). The cephalopods indicate a Late Famennian age (R. T. Becker, personal communication, 2012). A second fossilwas found about $60 \mathrm{~m}$ below the top of unit 1a (Fig. 10, "x" indicates fossil horizon). Units 2 and 3 include an interval of approximately 74 meters, and consist of dark greenish gray siltstones and shales interbedded with thin, but laterally continuous, limestones. Some siltstone beds in the lower part of unit 2 have pillow-shaped structures of unknown affinity (Fig. 12). Initial consideration of these beds as volcanic pillow structures has been replaced with hypotheses of a microbial origin. Stratigraphically above this siltstone interval is a 4 meter interval of fossiliferous green fissile shale with thin discontinuous limestone beds (Fig. 13). This is the primary interval yielding the fossils described by Ariunchimeg (2000). Higher in the section are a series of vertical siltstone beds with very abundant macrofossils including brachiopods, solitary rugose corals, branching bearing interval rich in brachiopods, rugose corals and crinoid ossicles 


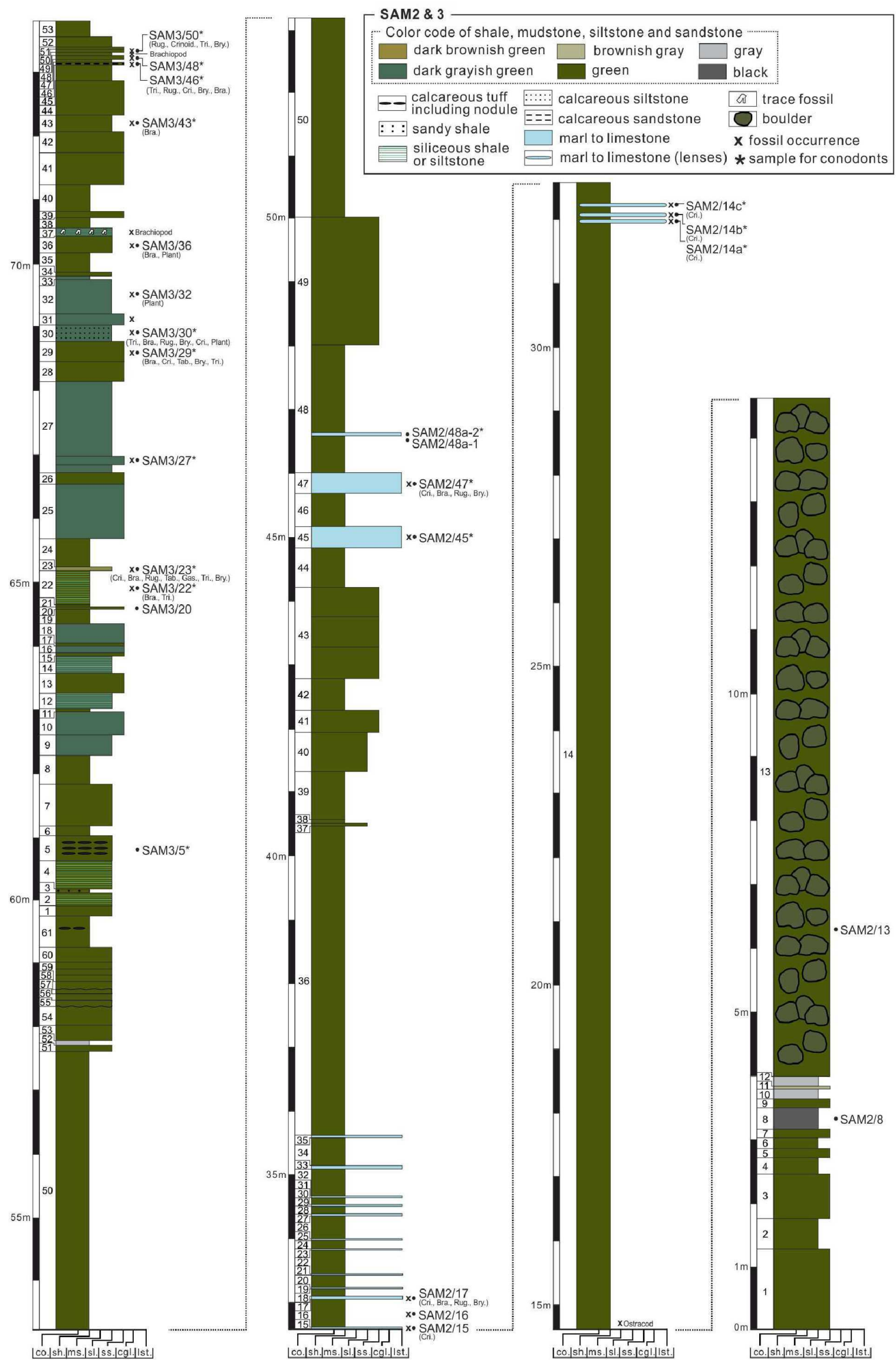

Figure 19. Measured columnar sections of units 2 and 3 (see Fig. 10 for extent of intervals). Sections provide details on the lithological content and show the stratigraphic position of collected samples for geochemistry and fossils (for abbreviation of rock types see Fig. 20). 


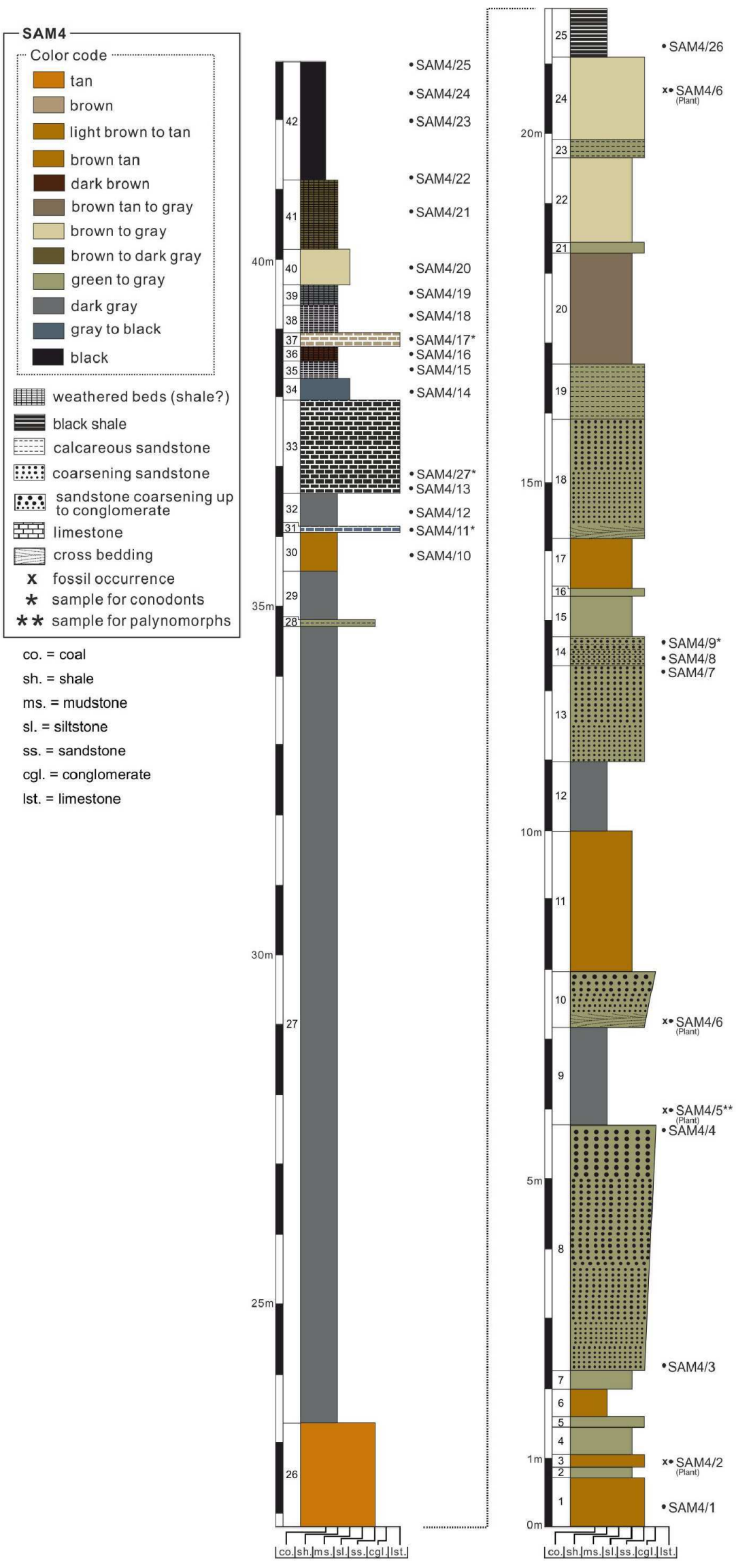

Figure 20. Measured columnar sections of unit 4 (stratigraphic continuity of Fig. 19). tabulate corals and phacopid trilobites (Fig. 14).

The top of the Samnuuruul Formation (= unit 4 ) is characterized by a series of coarsening upward sandstones and conglomerates, with interbedded siltstones and shales often containing macroscopic plant debris (Figs. 15, 16). This sequence grades upwards into a weathered shale culminating in a series of ?soil horizons, carbonaceous shales, and coal which likely cross the Devonian / Carboniferous boundary (Fig. 18). Within this transition is a 0.5 meter black shale (Fig. 17), which appears to be correlative with the Hangenberg Event. We conducted a detailed sampling scheme through this interval, and are awaiting the results of geochemical and palynological studies to further elucidate the events contained within this interval.

Additional two localities within the Samnuuruul Formation are Loc. 4 (45 $16^{\prime} 18^{\prime \prime}$; 91 03 '20"; Figs. 1 and 21 ) and Loc. 5 ( $45^{\circ} 05^{\prime} 02^{\prime \prime}$; 9134'13"; Figs. 1, 22-27), which were observed in the eastern outcrop belt of the formation to assess lateral facies changes. The first outcrop (Loc. 4) is located $7.5 \mathrm{~km}$ east of the Samnuuruul section. It consists of fossil-rich siltstones (Fig. 21), which can be correlated with unit 3 in the measured section. We collected a well preserved fauna of complete trilobite specimens, several $\mathrm{cm}$-large domal bryozoan colonies, large rugose corals and numerous articulated brachiopod shells here. The second outcrop (Loc. 5) is located $53 \mathrm{~km}$ east of the Samnuuruul section directly at the MongolianChinese border. There deposits have undergone low grade metamorphism, but contain a thick interval of well bedded highly fossiliferous slates (Fig. 22). On bedding planes large bivalves (Fig. 23), accumulations of spiriferid brachiopods (Fig. 24), rugose corals (Fig. 25), trilobites, bryozoan colonies, and even one articulated crinoid crown are found. Downhill, the sequence changes from a marine paleoenvironment (Devonian) into terrestrial deposits (Carboniferous) bearing megaplant fossils several meters long (Figs. 26 and 27).

\section{Discussion}

The Devonian deposits of the Baruunhuurai Terrane in western Mongolia are characterized by volcaniclastic rocks with intercalated fossil-rich marl to limestone lenses. These units were deposited on an island arc complex of the same tectonic terrane as similar Devonian units in the western and eastern Junggar in northwestern-China. Lithostratigraphically, the Middle to Late Devonian sediments of the western Junggar region are represented by the Hefen Formation (Eifelian; tuffaceous sandstone yielding brachiopods and corals, siltstone and tuffaceous conglomerate levels), Hujierste and Zhulumute formations 


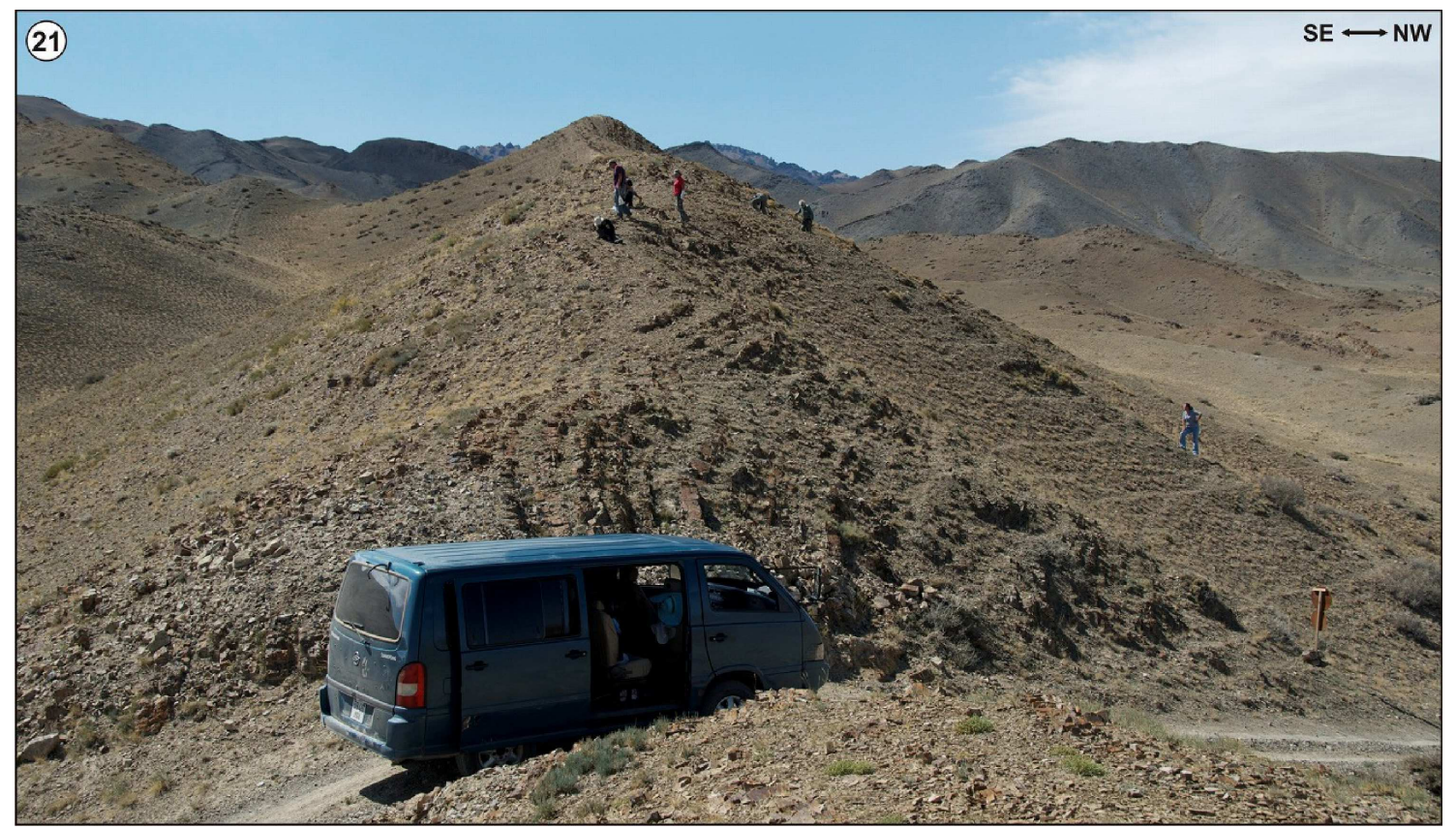

Figure 21. View of another locality exposing deposits of the fossil-rich unit 3 of the Samnuuruul Formation. The outcrop is located approx. $8 \mathrm{~km}$ east of the originally measured section (indicated as Loc. 4 in Fig. 1).

(Givetian to Frasnian; tuffaceous siliciclastic rocks yielding abundant plant fossils), and the Hongguleleng Formation (Frasnian to Famennian; shallow water carbonates intercalated with siltstones with a diverse fauna succeeded by a unit of radiolarian rich shale and chert) in ascending order. According to Wang et al. (2005) and Ma et al. (2009), the Middle to Upper Devonian in the eastern Junggar region is represented by the Ulusubasite Formation (Eifelian; sandstone, tuff and tuffaceous sandstone with plant fossils, and coral bearing limestone in the uppermost part), Zhifang Formation (Givetian; conglomerate levels at the base, tuffaceous sandstone and siliciclastic rocks with limestone nodules; fossils including plants, brachiopods and corals) and the Ke'ankuduk Formation (Frasnian to Famennian; lower unit: tuffaceous siliciclastics with plants, intercalated by radiolarian-chert; upper unit: tuffaceous sandstone intercalated with tuffaceous conglomerate).

Based on the sedimentology, a series of sea-level changes are recorded through the Middle to Late Devonian. In the western Junggar region, the boundary of the Hefeng Formation and Hujierste Formation is marked by a regression which was followed by a sea-level low-stand that persisted from the Givetian until the Late Frasnian. From the base of the Hongguleleng Formation onward a transgressive regime prevails. In the eastern Junggar region, a deepening is recorded in the Eifelian, which is followed by a regression at the transition between the Ulusubasite and Zhifang formations. Another regressive trend characterizes the boundary of the Zhifang and the Ke' ankuduk which is followed by deepening and subsequent shallowing to the top of the formation. Thus the western and eastern Junggar regions show a different sea-level history. Regional controls are inferred.

Our preliminary data indicate that the Eifelian to Frasnian Baruunhuurai Formation in the study area was deposited in a shallow marine nearshore setting with regionally dispersed limestone lenses produced by locally restricted fossil communities and intermittent volcanically derived sediment. The lithological content of the sequence shows characteristics of both areas in NW-China during the Eifelian, but seems to have a closer relation to the eastern Junggar region during the Givetian.

The Late Famennian Samnuuruul Formation is dominated by volcanically derived fine grained clastic deposition on a shallow shelf interspersed with sporadic deposition of limestone in the lower and middle part. The upper part of the formation consists of a series of sandstones perhaps deposited as a series of offshore bars or coastal barrier bars that grade upwards into a terrestrial coal producing sequence. The Samnuuruul Formation shares many biotic elements with the Hongguleleng Formation in western Junggar region of China, but seems to occupy a somewhat different sedimentary regime. The Hongguleleng Formation appears to represent a deepening sequence from a volcaniclastic sandstone to conglomerate dominated sedimentation at the top of the underlying unit followed by shallow water carbonates intercalated by siltstones overlain by radiolarian rich maroon and green shales. Although sedimentation across the D/ C-boundary appears to be conformable at the type locality of the Hongguleleng Formation, no sedimentological evidence of the Hangenberg Event is present. The Samnuuruul Formation contains a black shale interval in a stratigraphic position consistent with the Hangenberg Event. In contrast, the Late Famennian interval of the Ke'ankuduk Formation in eastern Junggar region consists of a noncarbonatic terrestrial development. As a result finding similar aged formations with strikingly different patterns of sedimentation between the sections in western and eastern Junggar regions and the Samnuuruul Formation in western Mongolia is not surprising, but the resulting geographic isolation provided the proper conditions to support ecological refugia, particularly in the aftermath of the Frasnian/Famennian event.

\section{Acknowledgements}

This research was funded from an NSF EAGER grant and an ROA contract to NSF DEB-1036260 (JAW), a grant from the University of Tennessee (JWA), FWF P 23775-B17 (EK \& TJS) and 

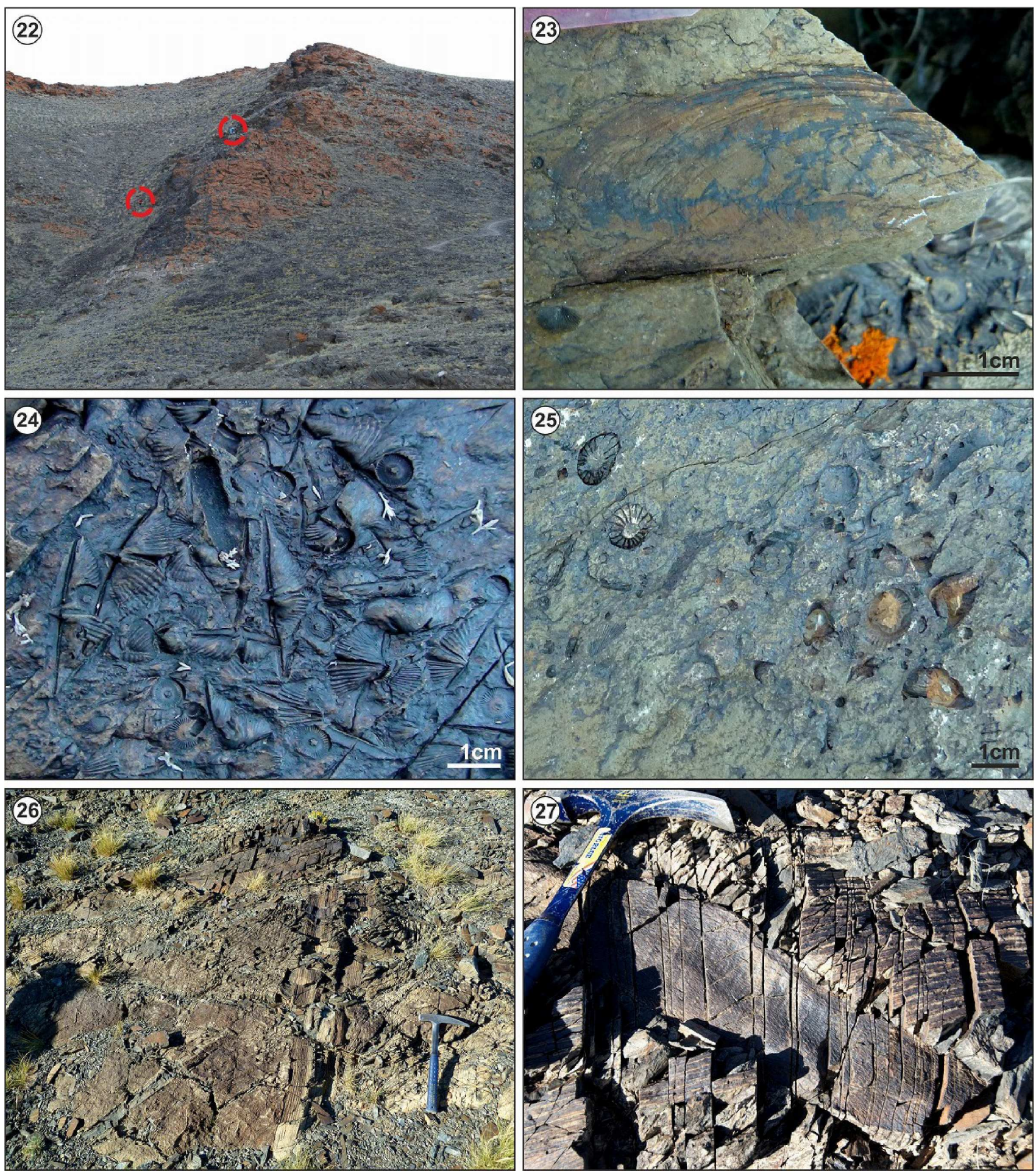

Figures 22-27. 22: Photo from the Samnuuruul Formation outcropping at the Mongolian-Chinese border (indicated as Loc. 5 in Fig. 1). Red circles indicate two colleagues who stood for scale near the fossil-rich horizons. 23: Large bivalve. 24: Dense accumulation of fossils on the rock surface, such as spiriferid brachiopods, bivalves, crinoid ossicles and trilobite exuvia. 25: Rugose corals. 26, 27: Densely packed plant fossils from a horizon stratigraphically above the Samnuuruul Formation.

IGCP 596 (Ariunchimeg Ya, SG). This article represents a first step for an international cooperation with Mongolian geoscientists within the framework of IGCP 596. We kindly acknowledge Dr. Tomurtogoo for discussion on the tectonic division of Baruunhurai Terrane with AY. Thanks are due to Yanlong Chen (University of Graz, Austria) for translation of some publications written in Chinese language.
Additionally we kindly thank our drivers Ya. Purevjav and G. Tsagaantsooj from Khovd for transporting us safely through the desert and mountains of western Mongolia. We gratefully acknowledge additional assistance in the field by L. Battaivan, Kh. Zorigt and B. Myagmartsend. Two anonymous reviewers are kindly thanked for constructive comments improving the quality of the manuscript. 


\section{References}

Algeo, T.J., and Scheckler, S.E., 1998, Terrestrial-marine teleconnections in the Devonian: Links between the evolution of land plants, weathering processes, and marine anoxic events: Royal Society of London Philosophical Transactions, ser. B, v. 353, pp. 113-128.

Ariunchimeg, Ya., 2000, The first finds of Famennian bryozoans in Mongolia: Paleontologicheskii Zhurnal, 2000 (1), pp. 45-48. [In Russian].

Aristov, V.A., and Nyamsuren, G., 1996, Age of the volcanic rocks in middle Palaezoic sediments of Southern Mongolia: Stratigraphy. Geological correlation, v. 6, no. 1, pp. 96-101. [In Russian].

Badarch, G., Byamba, J., Mahbadar, Ts., Minjin, Ch., Orolmaa, D., Tomurtogoo, O., and Khosbayar, Ts., 1998, Summary, in Tomurtogoo, O., Byamba, J., Badarch, G., Minjin, Ch., Orolmaa, D., Khosbayar, P., Chuluun, D., Makhbadar, Ts., and Bat-Ireedui, Ya., eds, Geological map of Mongolia, scale 1:1,000,000: Mineral Resources Authority of Mongolia, Geological Survey and Mongolian Academy of Sciences, Institute of Geology and Mineral Resources, Ulaanbaatar, pp. 1-30. [Translated into English by Tsetsgee, A.].

Bambach, R.K., Knoll, A.H., and Wang, S.C., 2004, Origination, extinction, and mass depletions of marine diversity: Paleobiology, v. 30, no. 4, pp. 522-542.

Bol'shakova, L.N., Bondarenko, O.B., Minjin, Ch., Ulimina, L.M., and Sharkova, T.T., 2003, Paleontology of Mongolia: Corals and Stromatoporoids, Moskow, Nauka, pp.199-256. [In Russian].

Cai, C.Y., 2000, Non-marine Devonian, in NIGP (Nanjing Institute of Geology, Palaeontology, Chinese Academy of Sciences), ed, Stratigraphical Studies in China (1979-1999): University of Science and Technology of China Press, Hefei, pp. 95-127. [In Chinese].

Chen, B., and Arakawa, Y., 2005, Elemental and Nd-Sr isotopic geochemistry of granitoids from the West Junggar foldbelt (NW China), with implications for Phanerozoic continental growth: Geochimica et Cosmochimica Acta, v. 69, no. 5, pp. 1307-1320.

Chen, Z.-Q., and Archbold, N.W., 2002, New chonostrophiid brachiopods from the Famennian (Late Devonian) of the Santanghu Basin, Xinjiang, Northwest China: Journal of Paleontology, v. 76, no. 2, pp. 229-238.

Chen, X.-Q., Mawson, R., Suttner, T.J., Talent, J.A., Frýda, J., Mathieson, D., Molloy, P., and Berkyová, S., 2009, Late Devonian (latest FrasnianFamennian) faunas from the 'Hongguleleng Formation' and the F-F boundary in northern Xinjiang, NW China (abs), in Suttner, T.J., Hubmann, B., and Piller, W.E., eds, Paleozoic Seas Symposium, Graz, 14-18th September 2009, Berichte des Institutes für Erdwissenschaften, Karl-Franzens-Universität Graz 14, Graz, pp. 18-20.

Cocks, L.R.M., and Torsvik, T.H., 2007, Siberia, the wandering northern terrane, and its changing geography through the Palaeozoic: Earth-Science Reviews, v. 82, no. 1-2, pp. 29-74.

Dergunov, A.B., ed, 2001, Tectonics, Magmatism, and Metallogeny of Mongolia: Routledge, London and New York; 228 pp. [Translated from Russian into English by Sorkina, R.E., Fursenko, R.V., and Miloradovskaya, E.A.].

Erlanger, O.A., 1994, Devonian Rhynchonellidae of Mongolia: Moskow, Nauka, Transaction of Russian-Mongolian Joint Pal. Exp. No. 45, 143pp. [In Russian].

Gong, Y., and Liu, B., 1993, Plate-tectonic Sedimentology of the Devonian Volcanic Sedimentary Successions in Northern Xinjiang, Northwestern China: The Press of the China University of Geosciences, 138 pp. [In Chinese and English translation].

Hou, H.-F., and Wang, S.-T. et al., 1988, Stratigraphy of China, no.7: The Devonian System of China: Geological Publishing House, Beijing; $348 \mathrm{pp}$.

Hou, H.-F., Lane, N.G., Waters, J.A., and Maples, C.G., 1993 [1994], Discovery of a new Famennian echinoderm fauna from the Hongguleleng Formation of Xinjiang, with redefinition of the formation: Stratigraphy and Paleontology of China, 2, pp. 1-18.

Hou, H., Cao, X., Wang, S., Xian, S., and Wang, J., 2000, Stratigraphic Lexicon of China: Devonian System: Geological Publishing House, Beijing, 119 pp. [In Chinese].

Jahn, B.M., Wu, F., and Chen, B., 2000, Granitoids of the Central Asian Orogenic Belt and continental growth in the Phanerozoic: Transactions of the Royal Society of Edinburgh-Earth Sciences, v. 91, pp. 181-193.

Lane, N.G., Waters, J.A., and Maples, C.G., 1997, Echinoderm faunas of the Hongguleleng Formation, Late Devonian (Famennian), Xinjiang-Uygur Autonomous Region, People's Republic of China: Memoir, Paleontological Society, 47, $43 \mathrm{pp}$.

Liao, W.-H., and Cai, T.-C., 1987, Sequence of Devonian rugose coral assemblages from northern Xinjaing: Gushengwu Xuebao [= Acta Palaeontologia Sinica], v. 26, no. 6, pp. 689-707, pls I-IV. [In Chinese with English summary].

Lu, L.-C., and Wicander, R., 1988, Upper Devonian acritarchs and spores from the Hongguleleng Formation, Hefeng District in Xinjiang, China: Revista Española de Micropaleontología, v. 20, pp. 109-148.

Ma, X.-P., Liao, W.-H., and Wang, D.-M., 2009, The Devonian System of China, with a discussion on sea-level change in South China, in Köningshof, P., ed, Devonian Change: Case Studies in Palaeogeography and Palaeoecology: The Geological Society, London, Special Publications 314, pp. 241-262.

Ma, X.-P., Zong, P., and Sun, Y.-L., 2011, The Devonian (Famennian) sequence in the western Junggar area, Northern Xinjiang, China: SDS Newsletter, v. 26 , pp. $44-49$.

McGhee, G.R., Sheehan, P.M., Bottjer, D.J., and Droser, M.L., 2012, Ecological ranking of Phanerozoicbiodiversity crises: the Serpukhovian (Early Carboniferous) crisis had a greater ecological impact than the end-Ordovician: Geology, v. 40, pp. 147-150.

McGhee, G.R., Clapham, M.E., Sheehan, P.M., Bottjer, D.J., and Droser, M.L., 2013, A new ecological-severity ranking of major Phanerozoic biodiversity crises: Palaeogeography, Palaeoclimatology, Palaeoecology, v. 370 , pp. $260-270$.

Raup, D.M., and Sepkoski, J.J., 1982, Mass extinctions in the marine fossil record: Science v. 215, pp. 1501-1503.

Sepkoski, J.J., 1996, Patterns of Phanerozoic extinction: a perspective from global data bases, in Walliser, O.H., ed, Global Events and Event Stratigraphy: Springer-Verlag, Berlin, pp. 35-51.

Sersmaa, G., 2001. Tsagaankhaalga Formation $\left(\mathrm{D}_{1-2}\right.$ tsh), in Webby, B., and Talent J., eds, Part II Mongolian Field Guide. pp. 47-48.

Soto, F., and B. Lin., 2000, Corales Rugosos de la Formacion Hongguleleng (Fameniense) en el N de Sinkiang (No De china): Geobios, v. 33, no. 5, pp. 527-541.

Stein, W.E., Mannolini, F., VanAller Hernick, L., Landing, E., and Berry, C.M., 2007, Giant cladoxylopsid trees resolve the enigma of the Earth's earliest forest stumps at Gilboa: Nature, v. 446, pp. 904-907.

Sullivan, N., 2010, The Eifelian Givetian boundary (Middle Devonian) at Tsakhir, Govi Altai Region, Southern Mongolia: 23rd Annual Keck Symposium, 2010 Houston, Texas, pp. 238-243.

Suttner, T.J., Kido, E., Chen, X.-Q., Mawson, R., Waters, J.A., Frýda, J., Mathieson, D., Molloy, P.D., Pickett, J., Webster, G.D., and Frýdová, B., accepted, Stratigraphy and facies development of the marine Late Devonian near the Boulongour Reservoir, northwest Xinjiang, China: Journal of Asian Earth Sciences.

Ulitina, L.M., 2001, Frasnian Rugosa from Mongolia: Paleontological Journal, v. 35 , no. 2 , pp. $125-129$.

Wainwright, A.J., Tosdal, R.M., Forster, C.N., Kirwin, D.J., Lewis, P.D., and Wooden J.L., 2011, Devonian and Carboniferous arcs of the Oyu Tolgoi porphyry $\mathrm{Cu}-\mathrm{Au}$ district, South Gobi region, Mongolia: Geological Society of America Bulletin, v. 123, no. 1-2, pp. 306-328.

Wang, J.-X., Xian, S.-Y., and Hou, H.-F., 2005, Devonian, in Centre for Stratigraphy and Palaeontology, China Geological Survey, ed, Stratigraphic division and correlation of each geological period in China: Geological Publishing House, Beijing, pp. 194-233. [In Chinese].

Waters, J.A., and Webster, G.D., 2009, A re-evaluation of Famennian echinoderm diversity: implications for patterns of extinction and rebound in the Late Devonian, in Köningshof, P., ed, Devonian Change: Case 
Studies in Palaeogeography and Palaeoecology: The Geological Society, London, Special Publications 314, pp. 149-161.

Waters, J.A., Maples, C.G., Lane, N.G., Marcus, S., Liao, Z.-T., Liu, L., Hou, H.-F., and Wang, J.-X., 2003, A quadrupling of Famennian Pelmatozoan diversity: New Late Devonian blastoids and crinoids from Northwest China: Journal of Paleontology, v. 77, no. 5, pp. 922-948.

Waters, J.A., Marcus, S.A., Maples, C.G., Lane, N.G., Hou, H.-F., Liao, Z.-T., Wang, J.-X., and Liu, L., 2008, Overview of Paleozoic stemmed echinoderms from China, in Ausich, W.I., and Webster, G.D., eds, Echinoderm Paleobiology: Indiana University Press, Bloomington, pp. 346-367.

Webster, G.D., and Waters, J.A., 2009, Late Devonian echinoderms from the Hongguleleng Formation of northwestern China, in Köningshof, P., ed, Devonian Change: Case Studies in Palaeogeography and Palaeoecology: The Geological Society, London, Special Publications 314, pp. 263-287.

Windley, B.F., Alexeiev, D., Xiao, W.-J., Kroner, A., and Badarch, G., 2007, Tectonic models for accretion of the Central Asian Orogenic Belt: Journal of the Geological Society, London, v. 164, no. 1, pp. 31-47.

Xia, F.-S., 1997, Marine microfaunas (bryozoans, conodonts and microvertebrate remains) from the Frasnian-Famennian interval in northwestern Junggar Basin of Xinjiang in China: Beiträge zur Paläontologie (Institut für Paläontologie, Universität Wien), v. 22, pp. 91-207.

Xiao, S.-L., Hou, H.-F., Wu, S.-Z., Wang, B.-Y., Wang, S.-R., Cai, T.-C.,
Gong, Y.-M., Yan, Y., and Cui, X., 1992, The Researches of Devonian System in North Xinjiang: Xinjiang Science Technology and Hygiene Publishing House (K), Urumqi, pp. 1-257 [In Chinese].

Xiao, W., Huang, B., Han, C., Sun, S., and Li, J., 2010, A review of the western part of the Altaids: A key to understanding the architecture of accretionary orogens: Gondwana Research, v. 18, pp. 253-273.

Xu, H.-K., 1991, Early and Middle Devonian boundary strata of Hoboksar, west Junggar and their brachiopods: Acta Palaeontologica Sinica, v. 30, no. 3, pp. 307-333. [In Chinese with English summary].

Xu, H.-K., 1999, Discovery of brachiopods from the Hujiersite Formation in west Junggar and its significance, in Nanjing Institute of Geology, Palaeontology, Academia Sinica, ed, Palaeozoic Fossils of Northern Xinjiang: Nanjing University Press, Nanjing, pp. 305-313. [In Chinese with English summary].

Zhao, Z.-X, 1986, The conodonts from Hobokasar Formation of Aljiati hill, northern Xinjiang: Xinjiang Petrolium Geology (Xinjiang Shiyou Dizhi), v. 7, no. 3, pp. 89-107.

Zhao, Z.-X., and Wang, C.-Y., 1990, Age of Hongguleleng Formation in Junggar Basin, Xinjiang, China: Journal of Stratigraphy, v. 14, no. 2, pp. 145-146.

Zhu, H.-C., Wicander, R., and Marshall, J.E.A., 2008, Biostratigraphic and paleogeographic significance of a palynological assemblage from the Middle Devonian Ulusubasite Formation, eastern Junggar Basin, Xinjiang, China: Review of Palaeobotany and Palynology, v. 152, pp. 141-157.

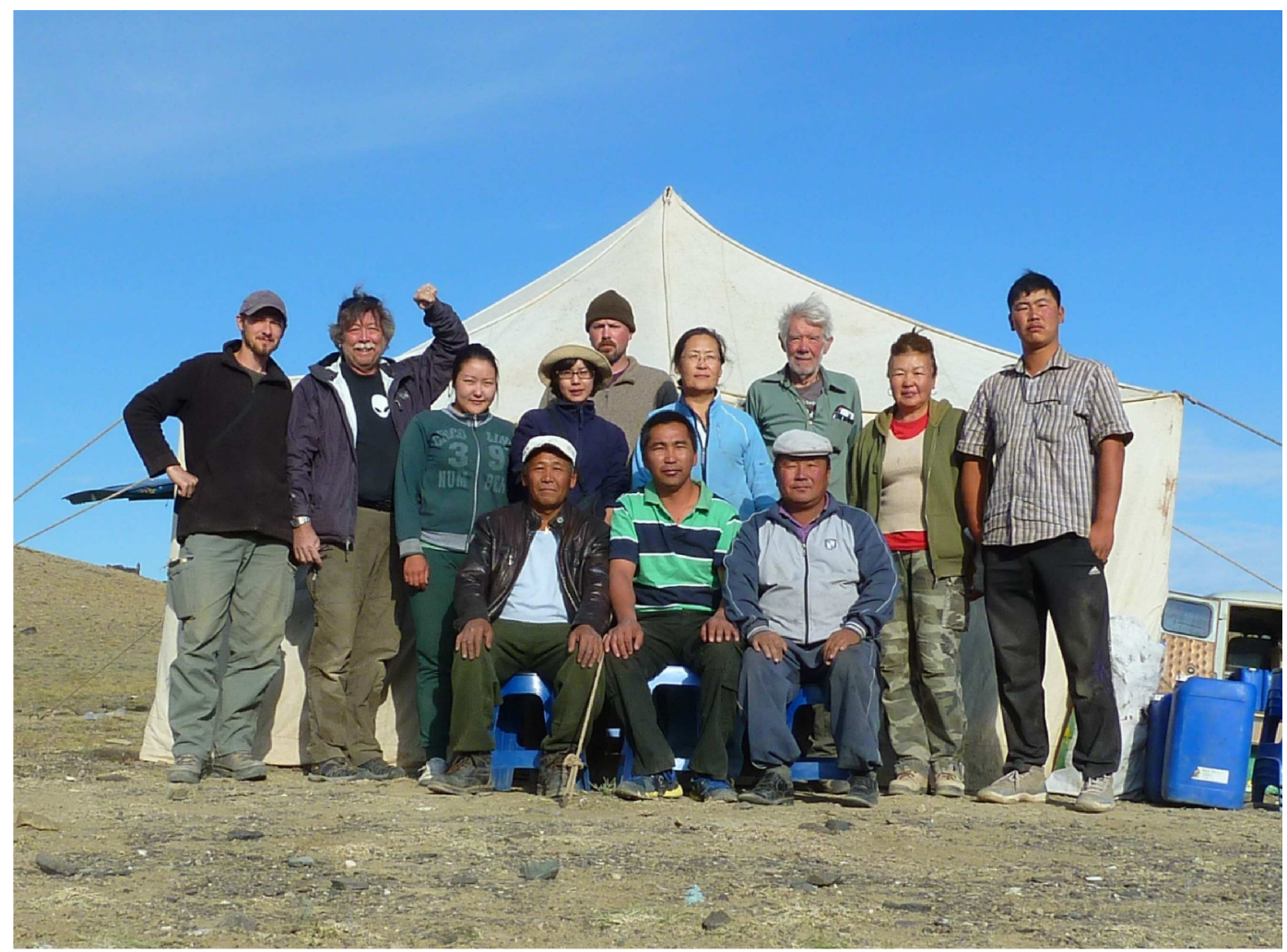

Photo of the Western Mongolia Devonian Working Group 2012. Ya. Purevjav, L. Battaivan and G. Tsagaantsooj (front row from left to right), B. Myagmartsend, E. Kido and G. Sersmaa (middle row from left to right), T.J. Suttner, J.A. Waters, J.W. Atwood, G.D. Webster, Ya. Ariunchimeg, and Kh. Zorigt (back row from left to right). 